\title{
'YOUR CHILD IS YOUR WHAKAPAPA': \\ MAORI CONSIDERATIONS OF ASSISTED HUMAN REPRODUCTION \\ AND RELATEDNESS
}

Marewa Glover and Benedicta Rousseau

\begin{abstract}
Based on data from the first study of Maori attitudes to assisted reproductive technologies, this article analyses the domaining of knowledge regarding biological and cultural reproduction. In particular, we examine the ways in which research participants portray whakapapa as an essential human and cultural resource, placed at the centre of considerations regarding relatedness and the appropriate use of AHR. The socio-political and historical circumstances of colonisation and Treaty settlement processes are investigated as contexts of 'possibility' that influence differing interpretations of whakapapa in relation to descent and contemporary kinship. In conclusion we suggest aspects of Maori concepts of relatedness and reproduction that warrant detailed ethnographic study in relation to contemporary political, economic and social change in Aotearoa/New Zealand.
\end{abstract}

\section{INTRODUCTION}

In 2005-06, Glover, McCree and Dyall (2007) from the Faculty of Medical and Health Sciences, University of Auckland, undertook the first study of Maori attitudes towards assisted human reproduction (AHR) (Glover 2008). This research addressed the previous lack of Maori voices in the relevant academic literature and added to the minimal involvement of Maori in the policy/ legislative literature (Atkin and Reid 1994, Hall and Metge 2002, Ruru 2005) regarding the appropriate framework for the use of AHR in Aotearoa/New Zealand. The research consisted of semi-structured interviews with fifteen key informants and six hui targeting particular constituencies within the Maori population. ${ }^{1}$ A flipchart or slide presentation was used to prompt discussion of Maori views on infertility. Participants were asked if they thought it important that Maori have good fertility and why and if it was important for Maori to 
have access to AHR. The various AHR interventions that are available in New Zealand were explained and participants were asked if they had any questions or comments. Participants were asked if there were any 'issues' for Maori with regard to the development of policy on AHR and the formulation or changing of legislation and what, if any, changes to current policy or legislation were needed?

The results of these discussions consist of a diverse range of statements and debate on issues beyond just the technologies of AHR, providing a broad insight into cultural considerations around reproduction and relatedness. Themes that emerged from the data revolved around comments on: the existence of cultural resources and discourses to understand technological change; the relationship between different Maori social groupings and reproduction of members; the analogous nature of extant cultural practices, particularly whangai/adoption; the links between essential cultural resources and reproduction; questions of when life begins in relation to conception and procreation; and considerations of the existence, prevalence and 'novelty' of infertility for Maori. These themes were additionally cross-cut by other concerns: for example, infertility was considered with reference to socio-economic disadvantage and resultant health problems; as a suppressed phenomenon due to stereotypes of Maori as 'over productive', often linked to negative images in circulation in Aotearoa/ $\mathrm{NZ}$ of Maori as more likely to be beneficiaries and/or 'teenage mothers'; and as a condition which was recognised and addressed in the past through Maori health practices (rongoa). Amongst this diversity of voices found in the data, commonalities may be discerned. Of particular relevance to our discussion are the ways in which reproduction was portrayed as a socially contextualised experience. This included the importance or relevance of AHR beyond the personal desire for a child. The 'mechanics' of AHR were always linked to the product - determinations of what might be un-natural or inappropriate were generally phrased in terms of problems that might arise for offspring, rather than the difficulties of the AHR process; and, perhaps linking those two strands together, reproduction of a child was repeatedly linked to reproduction of Maori as a whole - survival in a collective sense was considered to be the kaupapa orienting reproductive decision making.

The data collected has so far been disseminated through a number of channels - a summary report (Glover, McCree and Dyall 2007), conference presentations, an article on AHR issues for takatapui (Glover, McCree and Dyall, in press), and a comprehensive final report (Glover 2008). This article represents a further stage in the analysis process, seeking to link the research findings to 
relevant areas of academic investigation around the themes of kinship and AHR. We focus on the concept of whakapapa, used time and again as the conceptual framework for participants' considerations of relatedness, personhood and reproduction, and try to tease out the differing discourses surrounding this key cultural principle. Through this analysis we aim to situate the perspectives of Maori research participants within the extant body of anthropological analysis relating to AHR, and to explore the contribution our findings make to recent discussions of the possible and appropriate relationships and accommodations between new technologies relating to life and Maori cultural values and practice.

\section{ANTHROPOLOGY AND AHR}

The consideration of AHR has played a central role in the reinvigoration of kinship studies within anthropology over the past twenty years. It is often claimed that this body of literature was prompted to a large degree by the critique of previous approaches to kinship provided by the work of David Schneider $(1968,1984)$. His study made explicit 'the work of kinship' and revealed the underlying Eurocentric assumptions of anthropological approaches to the topic so far - a conflation of the biological with the social, and the natural with the cultural, embodied in the idiom of 'blood' as the essence of relatedness. As Franklin and McKinnon (2001) argue, though, a contextual reading of Schneider's work situates it within a broader shift in anthropology through the 1970 s to a questioning of 'natural facts'. In particular, feminist anthropologists sought to demonstrate the specificity of the nature/culture division to post-Enlightenment European thinking, thus undermining the structuralist argument for its universally applicable analytical power (e.g: MacCormack and Strathern 1980). Collier and Yanagisako's (1987) edited volume, Gender and Kinship: Essays toward a Unified Analysis, extended the critique by exploring the contingent relationship in anthropological thinking between gender-asnatural-fact and kinship-as-natural-fact:

Much of what is written about...kinship...is rooted in assumptions about the natural characteristics of women and men and their natural roles in sexual procreation. The standard units of our genealogies, after all, are circles and triangles about which we assume a number of things. Above all, we take for granted that they represent two naturally different categories of people and that the natural difference between them is the basis for human reproduction and, therefore, kinship (Yanagisako and Collier 1987:32). 
Despite demolishing the underpinnings of previous approaches to kinship, these critiques opened up to examination the multiple ways in which human beings are reproduced and related. The rise of reproductive technologies from the late 1970 s provided fertile ethnographic ground for such enquiry. Strathern's (1992) exploration of assisted reproduction and English kinship represents an early example of such investigations, and has been followed by influential contributions from Edwards (2000), Carsten (2004), Franklin (1997) and Edwards et al. (1999) amongst others. In keeping with anthropological interest in globalisation, the literature has expanded rapidly to explore the differing manifestations of AHR in diverse cultural contexts. Collections such as Ginsburg and Rapp (1995) and Rapp (2006) illustrate well the mutations of AHR technology as it has spread from its Euro-American birthplace. Anthropologists have demonstrated clearly the ways in which AHR can 'look' different dependent on the particular religious and/or national contexts in which it takes place. Key examples of such literature encompass the negotiations around AHR in Muslim countries (Inhorn 2005, Clarke 2006); the particular needs surrounding assisted reproduction in Israel where determinations of motherhood link with the inheritance of Jewishness and thus, citizenship (Kahn 2004); and the anxieties produced by the importation of donor sperm across national borders (Simpson 2000). Such analyses highlight the plurality of lenses through which reproduction and relatedness is viewed to the extent that it has become something of an anthropological truism that AHR is 'good to think'.

In Aotearoa/New Zealand social and cultural aspects of AHR have been investigated from a number of angles. Baker (2004) discusses the tensions experienced by (predominantly Pakeha) couples undergoing fertility treatments in Auckland, with particular reference to discourses of normality linked to heterosexual procreation. Shaw (2008) reports on research amongst egg donors and gestational surrogates in Aotearoa/New Zealand, analysing their donative acts with reference to sociological theories of gifting. Daniels (e.g. 2004) has written extensively on what he terms the 'psychosocial' aspects of AHR, especially the psychological and ethical implications of donation and anonymity.

Public documents can be considered to form part of the relevant body of literature in Aotearoa/New Zealand. Amongst these, Atkin and Reid (1994) represents an early step in the move towards a comprehensive legislative framework for AHR in this country. The development of the eventual Human Assisted Reproductive Technology Act 2004 has produced much 'grey literature' in the shape of expert and public submissions, supplementary order papers and parliamentary debate. Through its website, the New Zealand Bioethics Council (www.bioethics.org.nz) has encouraged and reported public debate on issues 
surrounding reproductive technologies, as well as providing official interventions on the topic (e.g. NZ Bioethics Council 2003). As was the case in Britain (Shore 1992; Franklin 1999), these have spurred anthropological interest for the insights into notions of relatedness and 'normality' around issues of reproduction that such documents provide. Park, McLauchlan and Frengley (2008) have explored these issues in relation to the public submissions on the (then) proposed HART legislation, and Park (in press) provides a comparative analysis of the discourses of personhood expressed by the 'general public' and those in the haemophilia community in Aotearoa/New Zealand. Also linked to the sphere of kinship and relatedness, Legge, Fitzgerald and Frank (2007) have outlined the interplay between lived experience of 'new' family structures linked to assisted reproduction and the legal testing of these in case law in the lead-up to 'official' recognition of non-traditional families through the 2004 legislation.

As the literature outlined here indicates, when people talk about AHR they rarely confine themselves to the intricacies and mechanics of particular technological interventions, engaging more in discussion of what constitutes human life and relationships. Our research participants were no exception to this. In the following section, we use their words to illustrate the creation of domains of knowledge which they considered appropriate/necessary to explaining how AHR might work for Maori. We argue that the concept of whakapapa provided the pivotal point around which this knowledge was built, yet the differing uses we outline of this central principle show the analytical ability of AHR to create 'possibility' and provide the context for commentary on contemporary social arrangements and imagined futures. (cf: Strathern 1995, 1999).

\section{WHAKAPAPA AND FERTILITY}

Given the topic of AHR, participants chose to discuss too, their understanding of fertility and infertility as the context in which it would be used. Here we see the centrality given to reproduction by and of Maori, with whakapapa frequently mentioned as the purpose of that process. One informant spoke of the threat to the survival of Maori with reference to 'the absolute importance of continuing or being able to assist in the continuity of Maori ancestry/whakapapa. This was framed too as an often gendered obligation. ${ }^{3}$ The particular issues surrounding reproduction for takatapui informants caused anxieties: 'In terms of continuing our whakapapa, that's been something that's been quite overwhelming for me. Women too tied fertility and sexual identity together through the perpetuation of whakapapa: 'we are here to propagate the next generation, your whakapapa'; 'women are produced to have children... 
to keep the whakapapa going'; 'we're put on this earth for a reason and it's to carry on whakapapa, and a lot of us take it very, very seriously'. Here we see whakapapa being closely tied to reproductive ability, appearing in fact as the thing that was to be reproduced - made obvious in the one statement, 'your child is your whakapapa'.

\section{WHAKAPAPA AND PERSONHOOD}

This interpretation was reinforced through further discussion and comments which, we argue, infer whakapapa to be an essential component of a person. Participants' thinking moved quickly beyond the mechanics of reproduction to a consideration of the futures of children conceived through AHR. As one informant explained, 'There's implications there in terms of identity...Traditional thinking has it that the nature of the person is in the mauri and that mauri comes down through the two parents'. As a result, more than two participants in procreation, or an unknown participant, ${ }^{4}$ raised concerns about the make-up of the child: 'Whose tapu? Whose mana? Whose mauri? Whose wairua? Whose hau? All these ingredients make up that tinana. That's the Maori notion of life - all those things together'. The assumptions underlying whakapapa as used by participants become clearer through comments on the discordance that AHR could produce: 'Our whakapapa's always based on you know your father, you know your mother, or you know your grandmother or you know your grandfather'. Here whakapapa is proposed to be primarily about the possibility of correct emplacement in a network of relationships. Singular connection via whakapapa represents an essential resource; personhood is contingent on (biological) relatedness.

\section{SINGULARITY AND REPRODUCTION}

An interesting consonance appears here between the kaupapa orienting reproduction as put forward by research participants, and the construction of personhood discussed above. A point that emerged clearly from this research was that any discussion of Maori fertility was underpinned by the need for Maori to continue to exist, often couched in terms of 'survival' and 'unique' identity as a group. As those two words suggest, discussion around this issue involved multiple references to biological considerations in determining identity of person and group. Despairing of the possibility of perpetuating a unique identity, one informant stated that 'we've already been watered down'; relationships between Maori and Pakeha were seen to produce 'half breeds', in one informant's words. For her, 'if one of my daughters goes off on to a Pakeha, well it's going to run to the Pakeha side'. How to instill - or, as one informant put 
it, 'inject'-Maoriness in offspring was a concern. For one kaumatua this was clear: 'As long as they got Maori blood in them, they're Maori...I remember having this talk to my mokopunas. I said to them, because I'm a Maori you're a Maori, end of story. No other story'. The sense that whakapapa was an innate quality that defined Maori was also of relevance in these discussions. 'Activating' whakapapa was seen as part of being Maori. Participants in the men's hui agreed that knowing that you have it wasn't enough; rather, you had to identify as Maori for your whakapapa to 'work'. The notion that an equivalent - or challenging-whakapapa might be inherited from a non-Maori parent was put forward as a reality, but not necessarily a hindrance to being Maori: children should be 'brought up in the sense that they don't have to choose between one or the other. They can have both and know that they're Maori'.

Through their discussions of what made 'a Maori' participants sought to define its properties/boundaries, and put together particular knowledge to produce Maori identity as something both unique and capable of reproduction. The biologically-expressed ideal of group survival is carried out through the creation of uniquely locatable persons. Whakapapa unites the two, carrying biological force and moral imperative in terms of reproduction; essence and definitional power in terms of personhood. Producing a child/whakapapa is the act of producing a unique node in a network of relatedness, with singular locatability being the measure of belonging. ${ }^{5}$

\section{COLONISATION AND (CULTURAL) REPRODUCTION}

The foregoing analysis has sought to show the domain of knowledge which Maori research participants create through the possibilities of AHR, but leaves unanswered the question of why these particular limits are chosen. Here we offer a consideration of another context, that of colonisation, which, in the same way as AHR, produces possibility, and provide some preliminary suggestions as to how each influences the other. Of relevance here are the experience of massive depopulation in the course of colonisation, the permutations of state attempts to define and enforce particular definitions of 'a Maori', and the impact of these factors on Maori considerations of fertility and survival.

As in many other such encounters, the colonisation of Aotearoa/New Zealand from the late eighteenth century onwards involved a radical depopulation of the indigenous people. This was due to a number of factors: introduced disease, diminished living conditions, warfare, deprivation of access to resources (land, fisheries, agriculture), lack of access to health care and lack of access to resources to continue indigenous health practices. These factors combined 
to reduce the Maori population from estimates of 150,000-200,000 in the early contact period to below 50,000 by the turn of the twentieth century. ${ }^{6}$ Salesa (2001) argues that this decline was conceptualised by colonialists in terms of the Maori 'body politic' as much, if not more, than specific Maori bodies. While depopulation engendered a sometimes paternalistic, and sometimes racistly-informed acceptance that the Maori 'race' would not survive, it also led to the development of authoritative discourses locating the blame for population decline in a Maori collective culture. As in other colonial contexts, practices and beliefs around reproduction (in its broadest sense - birthing, infanticide, indigenous medicine, marriage practices, residence patterns) were a particular focus of anxiety and intervention (for comparative examples see: Ram and Jolly 1998).

The tying together of Maori (cultural) reproduction and Maori decline in colonial medical discourse is indicative of the continuing project of encompassing, defining and legislating the boundaries of Maori within the new nation. While iwi continued to form a basis for collective action, governmental frameworks increasingly proposed a definable individual-level Maori identity. A salient example of this was the legislative provisions for Maori electoral participation which represented a move towards a biologically-determined delineation of the country's population. The Maori Representation Act 1867 brought into being the separate Maori electorates that continue to form part of Aotearoa/New Zealand's parliamentary makeup. This innovation supplemented the existing franchise under the New Zealand Constitution Act 1852 which provided voting rights to males over twenty-one, subject to various conditions relating to land ownership and/or income. While that wording did not explicitly preclude Maori men, an 1859 opinion from the Law Officers of the Crown indicated that Maori property rights based on communal land ownership and the principle of inalienability meant that they could not meet those criteria. The Native Land Acts of 1862 and 1865 aimed for a reformation of Maori ownership in line with European norms, but the delay in a significant proportion of Maori land becoming registered in private title meant that a short term 'solution' was needed to enfranchise Maori. The Act of 1867 granted voting rights in the four electorates to 'Maori males 21 and over, including half-castes' (Waitangi Tribunal 1994). 'Half-caste' here was determined as one European parent, reflecting both the relatively short time-span of interaction between Maori and Pakeha, and the increasing concern with biologically-informed measures of cultural affiliation.

The 'fractions of blood' model thus introduced/imposed cemented links between cultural particularity, inherited biological makeup and access to partici- 
pation in the nation-state. The overriding capacity of this form of definition is reinforced by the fact that those with Maori blood but who moved into European forms of social relationships necessitated specific legal provision: for example, the Licensing Act 1908 allowed Maori women married to Pakeha men to purchase alcohol for off-license consumption, something that was denied to all other Maori. Fractional calculation of 'race' continued as standard government statistical/definitional practice until 1971, and up to 1951 essential distinction between 'Maori' and 'European' was further enforced by separate censuses (Statistics New Zealand 2004).

The 1970s saw a shift away from the 'fractions of blood' approach in terms of both official statistics and electoral enrolment. The Maori Affairs Amendment Act 1974 put forward a definition based on ancestry, rather than a specific degree of 'Maoriness', indicating a move towards self-identity. This was reinforced by the introduction of the option to move between the Maori and General electoral rolls, and came soon after the Electoral Amendment Act 1967 which entitled Maori to stand for election in General seats (Waitangi Tribunal 1994). In the gathering of most official statistics, self-identity in terms of 'ethnicity' has been favoured by the Department of Statistics since 1988, although births, deaths and data from hospitals retained a 'fraction of blood' question for the calculation of 'ethnicity' up to 1995 (Statistics New Zealand 2004).

These frameworks for national-level delineation and classification of the population indicate a continuing historical link between biological descent and cultural specificity imposed on Maori. ${ }^{8}$ The move towards self-identity, while seen as bringing into alignment statistics and cultural values, is underpinned by similar assumptions. Defining 'ethnic groups', Statistics New Zealand offers the following characteristics: 'a social group whose members...share a sense of common origins; claim a common and distinctive history and destiny; possess one or more dimensions of collective cultural individuality; feel a sense of unique collective solidarity' (Statistics New Zealand 2004: 6). The relevant point here is not to say that self-identity is necessarily as flawed a system of classification as that which preceded it, but rather to suggest that assumptions of collective cultural coherence and resulting access to social inclusion are still being linked to descent, however it is reckoned; biological and cultural reproduction are still conflated.

THE WORK KINSHIP DOES

The preceding material suggests that Maori may, by necessity, be focused not so much on 'the work of kinship' (Schneider 1984), but rather on the work kin- 
ship does in enabling access to power and resources in Aotearoa/New Zealand. In recent years a further layer of 'work' has been added to Maori reproduction of identity through the Treaty settlement process currently pursued by the Crown, initiated in part by the Waitangi Tribunal Act 1975 and its later amendment of 1985. The particulars of the settlement process give preference to the existence of a 'large natural grouping' with whom the Crown (through the Office of Treaty Settlements [отs]) will conduct negotiations. In this way, iwi have become important and powerful corporate groupings, legally created and recognised through the parliamentary passage of settlements and conceived of as the 'natural' collective form for Maori.' Thus, iwi membership is critical to accessing the benefits of resources received through Treaty settlement. While state recognition of Maori corporate identity has a long history - tribal runanga of the mid-nineteenth century; councils, committees and Trust Boards through the twentieth century; the short-lived provisions of the Runanga Iwi Act 1990 - it can be argued that the present position of iwi as the key unit for Treaty settlement constitutes unique circumstances that contribute further to the tying together of biological and cultural reproduction. These circumstances relate to both the scale of dispersals through Treaty settlements, and the perceived (and stated) finality of these agreements. Each Deed of Settlement prepared through the отs consists of a definition of the group with whom settlement is being made, and a historical account of that group, including tribal ancestry and details of their rohe. Included in such Deeds is a section delineating membership of the group, listing ancestors from who descent should be traced, and names of hapu and whanau that members might come from. Thus membership of the iwi of Treaty settlements is in no way predicated on spatial location. The dispersed populations that make up the group may be living outside of the rohe, yet still qualify equally for corporate membership - through descent.

Proving legitimate membership of an iwi, and gaining subsequent access to resources through that membership, was an issue raised by informants when assessing the future position of children conceived through AHR. Alluding to the bureaucracy brought into being through the settlement process, involving registration of members on centralised iwi databases, one informant argued that such children 'could run into difficulties when it comes to getting education grants... Because in our corporate office....all the beneficiaries have to know their whakapapa back to a certain person'. To what extent whakapapa here might necessarily refer to blood descent appears to vary. Another informant declared that she would 'fight...tooth and nail' if her iwi enforced a biologically-based definition of whakapapa as criteria for membership as that 
would exclude those who claim membership by virtue of whangai or legal adoption.

Adoption according to tikanga, variously referred to as whangai, taurima or atawhai, ${ }^{10}$ appears to have provided the closest analogy for research participants with which to consider the whakapapa of children conceived through AHR. The majority of participant groups did discuss whangai at some point, as an alternative solution to infertility and as a signpost to potential problems surrounding AHR. The position of whangai children provides some indication of the extent to which inheritance and possession of whakapapa may be considered subject to biological measures. A brief assessment of authoritative comments on the matter though does indicate some variance. As Metge (1995) points out, the majority of whangai arrangements are between close relatives, generally within whanau, thus making issues relating to whakapapa less relevant as common descent is still there. On the other hand, the rarer instances of whangai from non-kin do have more negative connotations:

Though rare, it is not unknown for Maori to take unrelated children as tamariki atawhai. Such children are sometimes described as mokai rather than atawhai...It is, to say the least, $[a n]$ ambiguous [term]. On the one hand, it stresses inferior, dependent status; on the other, it often indicates a particularly strong bond, based entirely on affection....

[Such] relationships... are generally more brittle than those involving kinsfolk. They differ from atawhai relationships proper in that they are essentially relationships between individuals. They do not involve the whanau nor do they give the atawhai access to whanau rights. Atawhai of this kind are more likely to be resented by other whanau members. (Metge 1995: 217-18, my emphasis).

Metge's implication here is that such children may not be part of a network of relatedness, defying the necessary singular locatability in relation to others discussed above as the conceptual connective tissue between whakapapa and personhood.

In his discussion of whakapapa as the basis for social membership, Mead (2003) offers no comment on whangai, putting forward a model that emphasises the linguistic linkages of physical and social reproduction. Describing the bases of social membership, he asserts that 'locality by itself or even long association 
with a hapu, including years of toil at the local marae, do not qualify a person to membership of a hapu... The whakapapa principle and the simple fact of being born into the group is the most important and fundamental criterion of membership' (2003:218). He goes on to outline the linguistic analogies that, for him, cement this principle. The dual meaning of 'iwi' as 'bone' and as 'tribe' is discussed (Mead 2003: 219), and expanded upon:

Through time the association with bone has not changed. And this is important because the metaphor for the social unit above birth (whanau) and pregnancy (hapu) is bone. Relatives are often described as 'bones' and, in this sense, the members of an iwi are 'bones' which emphasises again the importance of shared whakapapa (Mead 2003: 219).

The tie of this physical structuring to whakapapa, and its importance to the 'body politic' is reiterated further:

Bones make a body strong and give form to it. Thus bones in the sense of whakapapa and in giving strength to anything is important in understanding the concept of iwi. The important aspect of the word iwi is its function as a metaphor for whanaungatanga and the strength that arises from that fact (Mead 2003: 219).

The extent to which this principle plays out in relation to the formation of iwi as corporate groups with reference to Treaty settlements appears to vary. A partial survey of Deeds of Settlement ${ }^{11}$ indicates a preponderance of iwi allowing whangai and often also legal adoption to confer descendant status on members (eg: Ngati Ruanui, Ngati Mutunga, Ngati Tama, Ngati Tuwharetoa, Ngati $\mathrm{Awa}^{12}$ ). Other iwi made no explicit statement on the topic, offering no qualifications to the criteria of descent from particular ancestors (eg: WaikatoTainui, Te Arawa). Two iwi did however specifically exclude whangai and legal adoption as criteria for claiming membership. Nga Rauru stated that: 'Ngaa Rauru Kiitahi wishes to place on the record that it considers it is for Ngaa Rauru Kiitahi, in accordance with Ngaa Raurutanga, to determine who is a member of Ngaa Rauru Kiitahi. Ngaa Rauru Kiitahi considers that:... Ngaa Uki o Ngaa Rauru Kiitahi is determined by whakapapa; and...adoption does not confer whakapapa on an individual' (Office of Treaty Settlements 2003:12-13). Similarly, Te Roroa stated that they 'wish to place on record that they consider that adoption does not confer whakapapa' (Office of Treaty Settlements 2005: 6). These examples are of interest due both to the apparent regional differentiation between, for example, Taranaki and Tai Tokerau with reference to 
biological descent and whakapapa, but also for the fact that these definitions are forming the basis of statutory bodies with the power to determine access to not insignificant resources. ${ }^{13}$

The relevance of political/historical circumstance to the interpretation of AHR is not confined to the examples we present here. Kahn's (2004) work on the use of reproductive technologies in Israel illustrates the accommodations that become necessary when reproduction and relatedness are tied to access to inclusion in the nation-state. For her research participants the process of conception was crosscut with concerns regarding the production of not just a child but a provably Jewish child, thus entitled to citizenship and social inclusion. In her ethnography, Kahn illustrates the network that becomes involved in reproduction in such a context - not just patient(s) and medical practitioners are involved, but also rabbis and maschgicha, older women who act as monitors ensuring religious rules are adhered to throughout the process of conception. Further ethnographic examples from Muslim countries (Inhorn 2005; Clarke 2006) indicate that decisions regarding relatedness and rights/inclusion conferred through particular group membership may seldom rest with individual parents or children.

\section{STRATEGIC NATURALIZING AND THE FLUIDITY OF RELATEDNESS}

It is important to stress here the preliminary nature of the data on which this article is based. The majority of the participants involved in hui did not have direct experience of AHR, or necessarily infertility. They were a predominantly self-selected group of interested people who, through the research process, became 'informed lay people'. The discussions on which we base our analysis need to be considered as explorations of the possibilities that AHR creates for Maori - conceived in both positive and negative terms. In setting out the particular domaining of knowledge that we perceive in these discussions and the contexts of possibility that may shape those domains, our aim is also to point to areas that warrant further ethnographic investigation. The problems identified here with regards to children conceived through AHR may be resolved through practical flexibility, the existence of which we can currently only speculate on.

Of comparative relevance here is Thompson's (2001) ethnographically informed account of 'strategic naturalizing' encountered in a United States fertility clinic. She outlines the discursive and practical accommodations reached by her informants in reconciling 'normal' kinship with assisted reproduction (in these cases, use of a donor egg). Examples that she discusses include shared 
life experience (in terms of ethnicity, class and upbringing) between donor and recipient being seen as 'enough' similarity to form the basis of a 'natural' affinity between gestational mother and child. Another informant found extant practices of 'dispersed parenting' in her African-American social milieu as an analogous platform from which to 'naturalise' the use of a donor egg. Thompson's informants thus offer a glimpse of the diverse strategies to 'bring about' relatedness that may be utilized in the face of what can be presented abstractly as problems.

Within the research discussed here fluidity and flexibility did find voice, especially in relation to participants' experience of whangai-based relationships, although this was not foregrounded in relation to discussions around whakapapa and relatedness. Ethnographic considerations of Maori kinship in action suggest too that this may here be the norm. Metge (1995) brings a temporal depth to her analysis of whanau, showing the expansions, contractions and accommodations that have occurred in the kinship practices of one group of Maori over fifty years. Ritchie (1963) discusses the strategic 'forgetting' of relatedness necessitated by a bilateral kinship system that might otherwise create an overwhelming network of obligation and avoidance. Both authors also show though how practices around kinship and determinations of relatedness are contingent on socio-political circumstances, such as land disputes and urbanization. For this reason, the consolidation of iwi through the Treaty settlement process may in fact have a strong effect on kinship for Maori and the associated domaining of knowledge around relatedness, and we suggest this as a valuable area for further study.

GLOSSARY OF MAORI TERMS

$\begin{array}{ll}\begin{array}{ll}\text { hapu } \\ \text { hau }\end{array} & \begin{array}{l}\text { pregnant; sub-tribe } \\ \text { sui }\end{array} \\ \text { soul, essence } \\ \text { meeting } \\ \text { tribe, bones } \\ \text { kaumatua } & \text { elders } \\ \text { kaupapa } & \text { philosophy } \\ \text { mana } & \text { integrity, charisma } \\ \text { marae } & \text { space of traditional meetings } \\ \text { mauri } & \text { life principle } \\ \text { mokai } & \text { pet } \\ \text { mokopuna } & \text { grandchildren } \\ \text { rangatahi } & \text { youth }\end{array}$




$\begin{array}{ll}\begin{array}{l}\text { rohe } \\ \text { runanga } \\ \text { takatapui }\end{array} & \begin{array}{l}\text { territory, district } \\ \text { council, institute } \\ \text { non-heterosexuals e.g. lesbian, gay, } \\ \text { transsexual, intersex, bisexual } \\ \text { child, children } \\ \text { tamariki }\end{array} \\ \begin{array}{l}\text { sapredness } \\ \text { the right way; custom; ethical system } \\ \text { tikanga }\end{array} & \text { body } \\ \text { tinana } & \text { spirit, soul } \\ \text { wairua } & \text { family, extended family; birth } \\ \text { whanau } & \text { relationship, kinship } \\ \text { whanaungatanga } & \text { to adopt/adopted person } \\ \text { whangai } & \text { ancestry } \\ \text { whakapapa } & \end{array}$

NOTES

1 Takatapui $(\mathrm{N}=6)$, health workers $(\mathrm{N}=11)$, kaumatua $(\mathrm{N}=17)$, consumers (of fertility services) $(\mathrm{N}=4)$, rangatahi $(\mathrm{N}=7)$ and men $(\mathrm{N}=7)$.

2 Franklin and McKinnon (2001:3) also make honourable mention of Edmund Leach, Ernest Gellner and Rodney Needham as early proponents of a flexible approach to the foundations and significance of kinship in social organization in reaction to the programmatic approach of structural functionalism.

3 The gendered nature of reproductive ideals as expressed by research participants is addressed in more detail by Glover (2008).

4 The 'issue' of anonymity of donors is addressed through the HART Act (2004) which set up a register of donors, donor offspring, donor offspring guardians and donor offspring siblings effective from 22 August 2005.

5 This interpretation is backed up by Roberts et al. (2004) who describe the links between knowledge, whakapapa and locatability: 'Given the relatively short period of human settlement in this country...it is possible for descendents alive today to recite from memory their whakapapa back to a canoe ancestor and thence to the ultimate source. This ability reinforces the importance of whakapapa as a way of knowing, of locating a person or a thing in time and in space... [T]o 'know' something is to be able to locate it within a whakapapa' (Roberts et al. 2004: 4). 
6 Debate continues around the extent and causes of depopulation. For an account of the colonial medical profession's perceptions of Maori population decline in the nineteenth century see Salesa (2001).

7 And Salesa argues that the authority given to medical voices in the first half of the nineteenth century was usurped by other 'experts' on the Maori 'body politic' from around 1860 onwards (2001: 40).

8 It could be argued that, by default, these are equally imposed on Pakeha. However, that ignores their position as the dominant group in Aotearoa/New Zealand and, for the most part, as those who devise the systems of classification.

9 See Sissons (2004) for a discussion of the disenfranchisement of urban Maori through government reluctance to recognise alternative corporate arrangements of Maori in fisheries quota negotiations and distributions.

10 The different terms for this practice reflect regional differences - atawhai for Tai Tokerau, taurima for Taranaki - with whangai having the widest distribution (Metge 1995: 211). We have chosen to use whangai here as this was the term used generally by informants.

11 All Deeds were accessed through the website of the Office of Treaty Settlements (www.ots.govt.nz).

12 It is interesting to note that, while Mead (2003) offers no explicit comment on the position of whangai and appears to put forward an equation of whakapapa and biological inheritance, he was also the chief negotiator for Ngati Awa and a signatory to this Deed of Settlement.

13 An anthropologist/historian with extensive experience of Treaty negotiation and settlement processes suggests that a move may be taking place to 'devolve' the potentially contentious decision of iwi membership down to whanau or hapu level. Rather than explicit exclusion on the basis of, for instance, whangai, iwi may prefer to define members simply as those recognised as members of a whanau or hapu within the iwi (John Hutton, pers.comm.).

\section{REFERENCES}

Atkin, W. R., and P. Reid, 1994 Assisted Human Reproduction: Navigating Our Future, Wellington: Department of Justice. 
Baker, Maureen 2004 'The Elusive Pregnancy: Choice and Empowerment in Medically-Assisted Conception', Women's Health and Urban Life III(1):34-55.

Carsten, Janet 2004 After Kinship, Cambridge: Cambridge University Press.

Clarke, Morgan 2006 'Islam, kinship and new reproductive technology', Anthropology Today 22(5):17-20.

Collier, Jane and Sylvia Yanagisako (eds), 1987 Gender and Kinship: essays towards a unified analysis, Stanford: Stanford University Press.

Daniels K. (2004) Building a family: With the assistance of donor insemination, Palmerston North, NZ: Dunmore Press.

Edwards, Jeanette, Sarah Franklin, Eric Hirsch, Frances Price and Marilyn Strathern (eds) 1999 Technologies of Procreation: Kinship in the Age of Assisted Conception, $2^{\text {nd }}$ edition, London and New York: Routledge.

Edwards, Jeanette 2000 Born and Bred: idioms of kinship and new reproductive technologies in England, Oxford: Oxford University Press.

Franklin, Sarah and Susan McKinnon 2001 'Introduction' in Sarah Franklin and Susan McKinnon (eds) Relative Values: Reconfiguring Kinship Studies, Durham: Duke University Press.

Franklin, Sarah 1997 Embodied Progress: A Cultural Account of Assisted Conception, London: Routledge.

Franklin, Sarah 1999 'Making Representations: The Parliamentary Debate on the Human Fertilisation and Embryology Act', in Jeanette Edwards, Sarah Franklin, Eric Hirsh, Frances Price and Marilyn Strathern (eds) Technologies of Procreation: Kinship in the Age of Assisted Conception, $2^{\text {nd }}$ edition London and New York: Routledge.

Ginsburg, Faye and Rayna Rapp (eds) 1995 Conceiving the new world order: the global politics of reproduction, Berkeley: University of California Press.

Glover, M. 2008 Maori attitudes to assisted human reproduction: An exploratory study, Auckland: Social and Community Health, School of Population Health, University of Auckland. 
Glover, Marewa, McCree, Alvie and Lorna Dyall 2007 Maori Attitudes to Assisted Human Reproduction: An Exploratory Study. Summary Report, Auckland: School of Population Health, University of Auckland.

Glover, MP, McCree, A. and L. Dyall (in press) 'Assisted Human Reproduction: Issues for Takatapui (New Zealand Indigenous Non-Heterosexuals)', Journal of GLBT Family Studies.

Hall D. and Metge J. 2002 'Kua tutu te puehe, kia mau: Māori aspirations and family law', in Henaghan M. and B. Atkin (eds) Family law policy in New Zealand, Wellington: Lexis Nevis Butterworths.

Inhorn, Marcia 2005 Religion and reproductive technologies: IVF and gamete donation in the Muslim world, Anthropology News 46(2): 14 and 18.

Kahn, Susan Martha 2004 'Eggs and wombs: the origins of Jewishness', in Robert Parkin and Linda Stone (eds) Kinship and Family: An Anthropological Reader, Oxford: Blackwell Publishing.

Legge, M., Fitzgerald, R., and N. Frank 2007 'A retrospective study of New Zealand case law involving assisted reproduction technology and the social recognition of 'new' family', Human Reproduction 22(1):17-25.

MacCormack, Carol P. and Marilyn Stathern (eds) 1980 Nature, Culture and Gender, Cambridge: Cambridge University Press.

Mead, Hirini M. 2003 Tikanga Maori: living by Maori values, Wellington: Huia.

Metge, Joan 1995 New Growth from Old: the whanau in the modern world, Wellington: Victoria University Press.

NZ Bioethics Council, 2003 Submission to the Health Select Committee on the Human Assisted Reproductive Technology ('HART') Bill sop No. 8o. Available online: http://www.bioethics.org.nz/publications/hart-submissionjulo3/index.html. Accessed: 10 April 2008.

Office of Treaty Settlements, 2003, Deed of Settlement of the Historical Claims of Ngaa Rauru Kiitahi. Available online: www.ots.govt.nz. Accessed: 14 April 2008. 
Office of Treaty Settlements, 2005, Deed of Settlement of the Historical Claims of Te Roroa. Available online: www.ots.govt.nz. Accessed: 14 April 2008.

Park, J. (in press) 'Concepts of Human Nature, Personhood and Natural/Normal in New Reproductive Technology Discourses in New Zealand', Anthropologica.

Park, J., L. McLauchlan, and E. Frengley 2008 Normal humaness, change and power in human assisted reproductive technology: An analysis of the written public submissions to the New Zealand Parliamentary Health Committee 2003, RAL-e 2. Auckland: Department of Anthropology, The University of Auckland.

Ram, Kalpana and Margaret Jolly (eds) 1998 Maternities and Modernities: colonial and postcolonial experiences in Asia and the Pacific, New York: Cambridge University Press.

Rapp, Rayna (ed.) 2006 'Sacred Conceptions: Religion and the Global Practice of IVF'. Special edition of Culture, Medicine and Psychiatry 30 (4).

Ritchie, James 1963 The Making of A Maori: a Case Study of a Changing Community, Wellington: A.H. and A.W. Reed.

Roberts, Mere, Brad Haami, Richard Benton, Terre Satterfield, Melissa L. Finucane et al., 2004 'Whakapapa as a Maori Mental Construct: Some implications for the Debate over Genetic Modification of Organisms', The Contemporary Pacific 16(1): 1-28.

Ruru J. 2005 'Indigenous peoples and Family Law: Issues in Aotearoa/New Zealand, International Journal of Law, Policy and the Family, 19(3):357-345.

Salesa, Toeolesulusulu Damon 2001 'The Power of the Physician: Doctors and the “Dying Maori” in Early Colonial New Zealand', Health and History 3:13-40.

Schneider, David 1968 American Kinship: A Cultural Account, Englewood Cliffs, NJ: Prentice Hall.

Schneider, David 1984 A Critique of the Study of Kinship, Ann Arbor: University of Michigan Press. 
Shaw, Rhonda 2008 'Rethinking Reproductive Gifts as Body Projects', Sociology 42(1): 11-28.

Shore, Cris 1992 'Virgin Births and Sterile Debates: Anthropology and the new reproductive technologies', Current Anthropology 33(3): 295-314.

Simpson, Bob 2000 'Imagined Genetic Communities: Ethnicity and Essentialism in the Twenty-first Century', Anthropology Today 16(3):3-6.

Sissons, Jeffrey 2004 'Maori Tribalism and Post-settler Nationhood in New Zealand', Oceania 75:19-31.

Statistics New Zealand, 2004 Report of the Review of the Measurement of Ethnicity. Available online: http://www.stats.govt.nz/NR/rdonlyres/33OAC1F7-72DB4CDA-A8ED-C29E7Bв03DDD/o/RME2004.pdf. Accessed: 10 April 2008.

Strathern, Marilyn 1992 Reproducing the Future: Anthropology, Kinship, and the New Reproductive Technologies, Manchester: Manchester University Press.

Strathern, Marilyn 1995 'Displacing Knowledge: Technology and the Consequences for Kinship', in Faye Ginsburg and Rayna Rapp (eds), Conceiving the new world order: the global politics of reproduction, Berkeley: University of California Press.

Strathern, Marilyn, 1999 'Regulation, substitution and possibility', in Jeanette Edwards, Sarah Franklin, Eric Hirsh, Frances Price and Marilyn Strathern (eds) Technologies of Procreation: Kinship in the Age of Assisted Conception, $2^{\text {nd }}$ edition London and New York: Routledge.

Thompson, Charis 2001 'Strategic naturalizing: kinship in an infertility clinic', in Sarah Franklin and Susan McKinnon (eds) Relative Values: Reconfiguring Kinship Studies, Durham: Duke University Press.

Waitangi Tribunal, 1994 Maori Electoral Option Report. Wai 413. Available online: http://www.waitangi-tribunal.govt.nz/scripts/reports/reports/413/. Accessed: 10 April 2008.

Yanagisako, Sylvia and Jane Collier 1987 'Introduction', in Jane Collier and Sylvia Yanagisako (eds) Gender and Kinship: essays towards a unified analysis, Stanford: Stanford University Press. 